\title{
ANALISIS PENGARUH MODEL PEMBELAJARAN KOOPERATIF TIPE GROUP INVESTIGATION DAN PEMAHAMAN KONSEP AWAL TERHADAP HASIL BELAJAR SISWA DI SMA NEGERI 1 TELUK MENGKUDU
}

\author{
Elida Tambunan dan Nurdin Bukit \\ Jurusan Pendidikan Fisika, Pascasarjana Universitas Negeri Medan
}

\begin{abstract}
Abstrak. Penelitian ini bertujuan: Untuk mengetahui apakah ada perbedaan hasil belajar fisika siswa dengan model pembelajaran kooperatif tipe group investigation dan model pembelajaran direct instruction, untuk mengetahui apakah ada perbedaan hasil belajar fisika antara siswa yang memiliki pemahaman konsep awal tinggi dan siswa yang memiliki pemahaman konsep awal rendah, untuk mengetahui apakah ada interaksi antara model kooperatif group investigation dengan pemahaman konsep awal siswa dalam mempengaruhi hasil belajar siswa. Sampel dalam penelitian ini dilakukan secara cluster random sampling sebanyak dua kelas, dimana kelas pertama sebagai kelas eksperimen diterapkan model pembelajaran kooperatif group Investigation dan kelas kedua sebagai kelas kontrol diterapkan model pembelajaran direct instruction. Instrumen yang digunakan dalam penelitian ini yaitu instrumen tes hasil belajar fisika dalam bentuk uraian sebanyak 9 soal dan tes pemahaman konsep awal sebanyak 12 soal yang telah dinyatakan valid dan reliabel. Dari hasil penelitian dapat disimpulkan bahwa terdapat perbedaan hasil belajar fisika siswa dengan model pembelajaran kooperatif group investigation dan model pembelajaran direct instruction. Terdapat perbedaan hasil belajar fisika antara siswa yang memiliki pemahaman konsep awal tinggi dan siswa yang memiliki pemahaman konsep awal rendah. Terdapat interaksi antara model pembelajaran kooperatif group investigation dan pemahaman konsep awal siswa terhadap hasil belajar fisika. Model pembelajaran kooperatif group investigation lebih optimal diterapkan untuk siswa yang memiliki pemahaman konsep awal tinggi sedangkan model pembelajaran direct instruction pemahaman konsep awal tinggi dan rendah hasil belajar yang tidak berbeda.
\end{abstract}

Kata kunci: group investigation, pemahaman konsep awal, hasil belajar

\section{THE ANALYZE EFFECTS OF COOPERATIVE LEARNING MODEL GROUP INVESTIGATION AND PRELIMINARY CONCEPTS UNDERSTANDING TOWARDS PHYSICS STUDENT LEARNING OUTCOMES IN SMA NEGERI 1 TELUK MENGKUDU}

\author{
Elida Tambunan and Nurdin Bukit \\ Physics Education Program, Graduate State University of Medan
}

\begin{abstract}
The purposes of the research are: to determine whether there is difference in student's physics learning outcomes with cooperative learning model group investigations and conventional learning model, to determine
\end{abstract}


there are differences in learning outcomes between students who have a physical preliminary concepts understanding of high and students who have a preliminary concepts understanding of of low, to determine the interaction between group investigation cooperative model with preliminary concepts understanding of students in influencing student learning outcomes. The sample in this study conducted in cluster random sampling of two classes, where first class as a class experiment applied cooperative learning model group investigation and second class as a class of control applied learning model of conventional learning model. The instruments used in this research achievement test physics of 10 questions in essay test and preliminary concepts understanding test as 12 questions that have been declared valid and reliable. From the results of this study concluded that there are differences in learning outcomes physics students with cooperative learning model group investigation and conventional learning model. There are differences in learning outcomes between students who have a physical preliminary concepts understanding of high and students who have a preliminary concepts understanding of of low. There is interaction between group investigation cooperative models with preliminary concepts understanding of students in influencing student learning outcomes. Learning outcomes of students who are taught by cooperative learning model of group investigation influenced also by understanding the initial concept, while the learning outcomes of students who were taught by the model of conventional learning.

\section{Keywords: group investigation, preliminary concept understanding, learning outcomes}

\section{PENDAHULUAN}

Pendidikan merupakan faktor utama dalam pembentukan pribadi manusia. Pendidikan sangat berperan dalam membentuk baik atau buruknya pribadi manusia menurut ukuran normatif. Menyadari akan hal tersebut, pemerintah sangat serius menangani bidang pendidikan, sebab dengan sistem pendidikan yang baik diharapkan muncul generasi penerus bangsa yang berkualitas dan mampu menyesuaikan diri untuk hidup bermasyarakat, berbangsa dan bernegara. Reformasi pendidikan merupakan respon terhadap perkembangan tuntutan global sebagai suatu upaya untuk mengadaptasikan sistem pendidikan yang mampu mengembangkan sumber daya manusia untuk memenuhi tuntutan zaman yang sedang berkembang. Melalui reformasi pendidikan, pendidikan harus berwawasan masa depan yang memberikan jaminan bagi perwujudan hak-hak azasi manusia untuk mengembangkan seluruh potensi dan prestasinya secara optimal guna kesejahteraan hidup di masa depan.

Hasil studi pendahuluan berupa observasi di SMA Negeri 1 Teluk Mengkudu di temukan bahwa proses belajar mengajar fisika masih menggunakan sistem direct instruction dengan pembelajaran langsung dimana guru mendominasi pembelajaran meskipun divariasi tanya jawab dengan siswa. Guru lebih banyak menyampaikan materi secara langsung kepada siswa. Hal ini menunjukkan bahwa pembelajaran fisika masih dilakukan secara transfer of Knowledge sehingga pembelajaran cenderung verbal dan berorientasi pada kemampuan kognitif siswa tanpa mempertimbangkan proses untuk memperoleh pengetahuan tersebut. Fenomena mengajar yang kurang melibatkan 
siswa secara langsung dalam kegiatan belajar mengajar menyebabkan kemampuan psikomotor dan afektif siswa kurang. Siswa jarang berdiskusi dan bekerja sama dengan siswa lain yang mengakibatkan siswa menjadi pasif. Kebanyakan siswa hanya berorientasi pada kemampuan kognitif saja serta menganggap bahwa fisika merupakan mata pelajaran yang menghafal. Sehingga pemahaman konsep awal siswa rendah terhadap fisika mengakibatkan hasil belajar rendah, terlihat dalam study pendahuluan yang ditemukan selama proses belajar mengajar dalam soal pemahaman konsep masih di bawah Kriteria Ketuntasan Minimal (KKM) yang di tetapkan SMA N 1 Teluk mengkudu pada mata pelajaran fisika adalah 70, yaitu siswa dikatakan tuntas belajar secara individu bila telah memperoleh skor $75 \%$ dari skor total, dan ketuntasan klasikal tercapai bila dikelas tersebut $\geq 85 \%$. Sehingga setiap tes formatif (evaluasi per kompetensi dasar) diperoleh hanya $\pm 30 \%$ siswa yang mencapai KKM.

Ketidak tertarikan siswa dalam mengikuti pembelajaran fisika ini mengakibatkan hasil belajar fisika siswa yang masih rendah. Rendahnya hasil belajar fisika ini diindikasi dengan jarangnya siswa mengajukan pertanyaan kepada guru dan seringnya siswa melakukan tindakan kecurangan disaat ujian berlangsung, apalagi ketika ujian nasional diadakan terdapat kebocoran soal. Hal ini merupakan dampak terbesar dari rendahnya pemahaman konsep awal yang dimiliki siswa. Salah satu penyebab lain rendahnya hasil belajar siswa dapat bersumber dari penggunaan model direct instruction, dimana pembelajaran sebagian besar masih berpusat pada guru. Siswa dengan pemahaman konsep awal yang rendah cenderung akan lebih pasif dalam proses pembelajaran. Pada model direct intruction peluang siswa untuk memunculkan pemahaman konsep awal sangatlah rendah. Hal ini dikarenakan pada model pembelajaran direct instruction kegiatan pembelajaran fisika yang berlangsung hanya bersifat transfer pengetahuan dari guru kepada siswa. Hal inilah
Jurnal Pendidikan Fisika

p-ISSN 2252-732X

e-ISSN 2301-7651

menyebabkan siswa kurang memiliki peran aktif dalam proses dan pengkonstruksian pengetahuan dalam dirinya. Siswa cenderung hanya menghafalkan fakta-fakta dan konsepkonsep tanpa mengetahui bagaimana fakta dan konsep itu terbentuk. Dan pada akhirnya membuat hasil belajar siswa hanya terbatas pada pemahaman konsep rendah yaitu mengingat dan memahami, sedangkan pemahaman konsep tinggi siswa akan rendah karena tidak diaktifkan selama kegiatan pembelajaran di kelas.

Seperti yang kita ketahui, Dick dan Carey (2005) menjelaskan bahwa kemampuan awal adalah kemampuan yang dimiliki seorang siswa pada saat akan memasuki suatu proses pembelajaran yang merupakan dasar (preriquisite) bagi siswa dalam melaksanakan kegiatan belajar akan bermanfaat dalam mempelajari pelajaran selanjutnya. Kemampuan awal merupakan pemahaman konsep awal memiliki peran tersendiri dalam memotivasi diri siswa dalam melaksanakan pembelajaran sains karena dengan memiliki pemahaman konsep yang tinggi siswa akan terdorong untuk menggali lebih jauh untuk menjawab dari ras ingin tahu yang dimiliki siswa. Piaget (Dahar, 2011) menyebutkan bahwa perkembangan intelektual merupakan suatu konstruksi dari satu sisi struktur-struktur mental. Setiap struktur baru didasarkan pada kemampuan-kemampuan tertentu sebelumnya, tetapi pada saat yang sama melibatkan hasil-hasil pengalaman. Pengetahuan tidak diperoleh secara pasif oleh seseorang, melainkan melalui tindakan. Perkembangan kognitif anak bergantung pada seberapa jauh mereka aktif memanipulasi dan berinteraksi dengan lingkungannya. Kegiatan memanipulasi dan berinteraksi dengan lingkungan ini akan memunculkan informasi dan pengalaman baru. Dalam hal ini informasi dan pengalaman baru merupakan realita yang dihadapi seseorang. Selanjutnya jika realita ini mengakibatkan ketidakseimbangan maka orang tersebut diberi kesempatan membangun pengetahuan baru atau memodifikasi pengetahuan sebelumnya melalui realita tersebut. Dengan 
demikian proses interaksi antara pikiran dan realita menempati posisi penting dalam proses membangun pengetahuan. Siswa dapat menstruktur hal-hal yang ada dalam pikirannya melalui realita yang dihadapinya. Jadi adanya informasi dan pengalaman baru sebagai realita mengakibatkan terjadinya rekonstruksi pengetahuan yang lama.

Salah satu model pembelajaran yang cocok digunakan dalam pembelajaran fisika yaitu model pembelajaran kooperatif. Kooperatif Group investigation merupakan salah satu model pembelajaran kooperatif dimana para peserta didik secara kolaboratif dalam kelompoknya memeriksa, mengalami dan memahami topik kajian yang akan dipelajari. Model koperatif ini memiliki manfaat untuk melatih peserta didik untuk menerima perbedaan pendapat dan bekerja dalam melakukan penyelidikan untuk memecahkan masalah bersama-sama dengan peserta didik lain yang berbeda latar belakangnya (Joyce et al, 2011).

\section{METODE PENELITIAN}

Penelitian ini akan dilaksanakan pada Semester I Kelas XI di SMA N Teluk Mengkudu yang beralamat Di Desa Pematang Guntung Kecamatan Teluk Mengkudu Tahun Ajaran 2014/2015. Penelitian ini akan dilaksanakan pada bulan Januari 2015. Populasi dalam penelitian ini adalah seluruh siswa kelas $\mathrm{X}$ SMA Negeri 1 Teluk Mengkudu yang seluruhnya berjumlah 3 (tiga) kelas. Masingmasing kelas terdiri dari 36 siswa sehingga populasi berjumlah 108 siswa. Pengambilan sampel dilakukan dengan cara cluster random sampling. Sampel diambil sebanyak 2 kelas (36 orang) dari jumlah pupulasi kemudian sampel tersebut dibagi menjadi dua kelas yaitu eksperimen 1 dengan menggunakan model pembelajaran Group Investigation dan kelas eksperimen 2 dengan menggunakan model pembelajaran Direct Instruction.

Penelitian ini termasuk jenis penelitian quasi eksperimen, dengan desain penelitiannya berupa Two Group Pretes-Postes Design.

Adapun desain penelitian untuk ANAVA $2 \times 2$ adalah seperti ditunjukkan pada Tabel 1.

Tabel 1. Desain Penelitian ANAVA

\begin{tabular}{cccc}
\hline Motivasi & \multicolumn{2}{c}{ Model Pembelajaran (A) } & Rata- \\
$\begin{array}{c}\text { Siswa } \\
(\mathrm{B})\end{array}$ & $\begin{array}{c}\text { Group } \\
\text { Investigation } \\
(1)\end{array}$ & $\begin{array}{c}\text { Direct } \\
\text { Instruction } \\
(2)\end{array}$ & \\
\hline $\begin{array}{c}\text { Rendah } \\
(1)\end{array}$ & $\mu_{11}$ & $\mu_{12}$ & $\mu_{R}$ \\
\hline $\begin{array}{c}\text { Tinggi } \\
(2)\end{array}$ & $\mu_{21}$ & $\mu_{22}$ & $\mu_{T}$ \\
\hline $\begin{array}{c}\text { Rata- } \\
\text { Rata }\end{array}$ & $\mu_{K}$ & $\mu_{e}$ & \\
\hline
\end{tabular}

Keterangan:

$\mathrm{A}_{1} \mathrm{~B}_{1}$ : Hasil belajar fisika kelompok siswa yang diberi perlakuan pembelajaran Direct Instruction dengan memiliki pemahaman konsep awal

$\mathrm{A}_{2} \mathrm{~B}_{1}$ : Hasil belajar fisika kelompok siswa yang diberi perlakuan pembelajaran model Kooperatif Tipe GI dengan memiliki pemahaman konsep awal tinggi

$\mathrm{A}_{1} \mathrm{~B}_{2}$ : Hasil belajar fisika kelompok siswa yang diberi perlakuan dengan pembelajaran Direct Instruction dan memiliki pemahaman konsep awal rendah

$\mathrm{A}_{2} \mathrm{~B}_{2}$ : Hasil belajar fisika kelompok siswa yang diberi perlakuan dengan pembelajaran Kooperatif tipe GI dan memiliki pemahaman konsep awal rendah.

$\mu_{\mathrm{A} 1} \quad$ : Rata-rata hasil belajar fisika siswa yang diajar dengan model direct intruction.

$\mu_{\mathrm{A} 2} \quad$ : Rata-rata hasil belajar fisika siswa yang diajar dengan model kooperatif GI

$\mu_{\mathrm{B} 1} \quad$ : Rata-rata hasil belajar fisika siswa yang mempunyai pemahaman konsep awal tinggi

$\mu_{\mathrm{B} 2} \quad$ : Rata-rata hasil belajar fisika siswa yang mempunyai pemahaman konsep awal rendah

\section{HASIL PENELITIAN DAN PEMBAHASAN}

Penelitian ini bertujuan untuk melihat analisis perbedaan hasil belajar Fisika siswa dengan penerapan model pembelajaran Group Investigation dan model pembelajaran Direct 
Instruction, analisis perbedaan Pemahaman Konsep Awal siswa dengan penerapan model pembelajaran Group Investigation dan model pembelajaran Direct Instruction, dan analisis interaksi antara model pembelajaran Group Investigation dan Direct Instruction dengan Pemahaman Konsep Awal siswa dalam meningkatkan hasil belajar Fisika.

Deskripsi data yang disajikan dalam penelitian ini terdiri dari skor Hasil Belajar (HB) dengan menggunakan model pembelajaran Group Investigation (GI) dan Direct Instruction (DI) yang dikelompokkan atas Pemahaman Konsep Awal siswa tinggi dan rendah. Secara ringkas, data hasil belajar pretes kelas Direct Instruction dan kelas Group Investigation dapat dilihat dari Gambar 1.

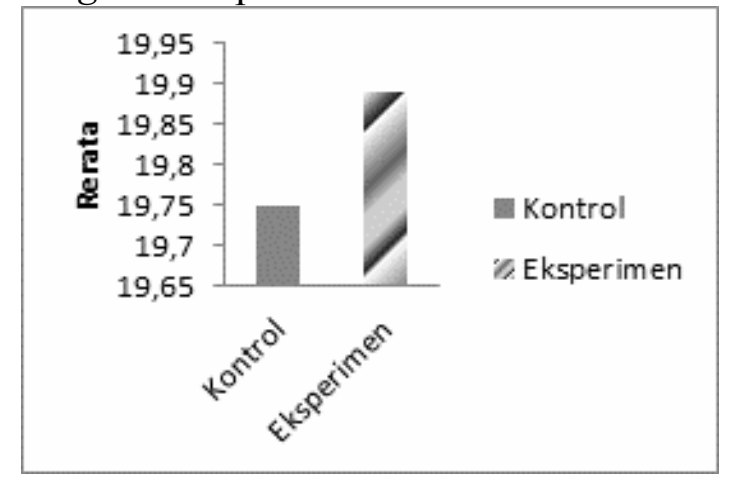

Gambar 1. Hasil Belajar Pretes Kelas DI Dan GI

Pengujian dilakukan dengan menggunakan SPSS 16.0 dengan uji t sampel bebas. Maka kedua data tersebut diuji normalitas dan homogenitasnya terlebih dahulu. Uji normalitas belajar ditunjukkan pada Tabel 2.

Tabel 2. Uji Normalitas Hasil Belajar Siswa

\begin{tabular}{cccccc}
\hline $\mathrm{N}$ & Kelas & $\mathrm{L}_{\text {hitung }}$ & $\mathrm{L}_{\text {tabel }}$ & Sig. & Ket. \\
\hline 1 & Kontrol & 0,130 & 0,161 & 0,130 & Normal \\
\hline 2 & Eksperimen & 0,116 & 0,161 & 0,200 & Normal \\
\hline
\end{tabular}

Uji kesamaan varians dan rata-rata nilai pretes dilakukan dengan test of homogenety of variance menggunakan spss 16.0 dengan hasil pengujian pada Tabel 3 .
Tabel 3. Hasil Uji Homogenitas Varians Pretes Kelas Eksperimen dan Kelas Kontrol

\begin{tabular}{cccccc}
\hline $\begin{array}{r}\mathrm{N} \\
\mathrm{o}\end{array}$ & $\begin{array}{c}\text { Homo } \\
\text { genitas }\end{array}$ & Fhitung & Ftabel & Sig. & Ket. \\
\hline 1 & Nilai & 0,397 & 4,00 & 0,531 & Homogen \\
\hline
\end{tabular}

Hasil pengujian yang terdapat pada Tabel 4.6, memperlihatkan nilai $\mathrm{F}_{\text {hitung }}$ untuk hasil belajar 0,397 dengan signifikansi $0,531\left(\mathrm{~F}_{\text {hitung }}=\right.$ $4,00, \alpha=0,05)$. Berdasarkan hasil tersebut $F_{\text {hitung }}$ $<\mathrm{F}$ tabel dan signifikan hitung lebih besar dibandingkan $\alpha=0,05$ sehingga dapat disimpulkan data pretes hasil belajar kelas kontrol dan kelas eksperimen memiliki varians yang sama. Uji kesamaan varians dan rata-rata nilai pretes dilakukan dengan uji t sampel bebas menggunakan spss 16.0 dengan hasil pengujian pada Tabel 4.

Tabel 4. Uji Kesamaan Kemampuan awal Hasil Belajar kelas Eksperimen dan kelas Kontrol

\begin{tabular}{cccccc}
\hline No & Uji Kesamaan & $\mathrm{t}_{\text {hitung }}$ & $\mathrm{F}_{\text {tabel }}$ & Sig. & Ket. \\
\hline 1 & Uji t & 0,172 & 1,67 & 0,899 & Sama \\
\hline
\end{tabular}

Tabel 4. diperoleh pengujian Hasil Belajar dengan hasil $t_{\text {hitung }} 0,172$ dan signifikansi sebesar $0,899\left(\mathrm{t}_{\text {tabel }}=1,67, \alpha=0,05\right)$. Hasil ini menunjukkan bahwa $-t_{\text {hitung }}>t_{\text {tabel }}>t_{\text {hitung }}$ dan nilai signifikansi lebih besar dibandingkan 0,05. Berdasarkan hasil tersebut disimpulkan bahwa tidak ada perbedaan kemampuan awal hasil belajar di kelas eksperimen dengan kelas kontrol.

Berdasarkan hasil penelitian nilai pemahaman konsep awal (PKA) siswa ditunjukan pada Tabel 5.

Tabel 5. Data PKA Siswa Kelas Kontrol dan Kelas Eksperimen

\begin{tabular}{cccc}
\hline \multicolumn{2}{c}{ Kelas Kontrol } & \multicolumn{2}{c}{ Kelas Eksperimen } \\
\hline Nilai & Frek & Nilai & Frek \\
\hline 5 & 11 & 5 & 11 \\
\hline 6 & 9 & 6 & 8 \\
\hline 7 & 7 & 7 & 6 \\
\hline 8 & 5 & 8 & 6 \\
\hline 9 & 3 & 9 & 3 \\
\hline 10 & 1 & 10 & 2 \\
\hline Jumlah & 36 & Jumlah & 36 \\
\hline Rerata & 6.52 & Rerata & 6.67 \\
\hline
\end{tabular}


Tabel 5 terlihat bahwa kelas kontrol memiliki rerata hasil belajar dengan nilai 6,52 dan kelas eksperimen memiliki rerata hasil belajar dengan nilai 6,67. Untuk pembagian kelompok tinggi dan rendah maka data diatas dibagi dalam 2 (dua) kelas seperti tabel 6 .

Tabel 6. Pembagian Kelompok PKA

\begin{tabular}{lrr}
\hline $\mathrm{N}$ & Valid & 72 \\
\cline { 2 - 3 } & Missing & 0 \\
\hline Mean & 6.5972 \\
\hline Median & 6 \\
\hline Std. Deviation & 1.47905 \\
\hline Percentiles & 50 & 6 \\
\hline
\end{tabular}

Data pemahaman konsep awal kedua kelas ini dikelompokan menjadi 2 (dua) kelompok berdasarkan nilai tengah (median) yaitu kelompok tinggi dan rendah dengan interval yang dapat dilihat pada Tabel 7 .

Tabel 7. Pembagian Kelompok PKA Rendah dan tinggi

\begin{tabular}{lccc}
\hline \multirow{2}{*}{ Kelompok } & \multirow{2}{*}{ Interval Skor } & \multicolumn{2}{c}{ Jumlah } \\
\cline { 3 - 4 } & & DI & KGI \\
\hline Rendah & $5-6$ & 20 & 19 \\
\hline Tinggi & $7-10$ & 16 & 17 \\
\hline
\end{tabular}

Data postes siswa dikelompokan berdasarkan model pembelajaran dan kelompok pemahaman konsep awalnya. Berdasarkan hasil penelitian nilai postes hasil belajar siswa ditunjukkan pada Tabel 8 .

Tabel 8. Data Hasil Belajar Siswa Berdasarkan Model dan PKA

\begin{tabular}{cccccccc}
\hline \multicolumn{2}{c}{ DI- PKA Rendah } & \multicolumn{2}{c}{ DI- PKA Tinggi } & \multicolumn{2}{c}{ KGI- PKA Rendah } & \multicolumn{2}{c}{ KGI- PKA Tinggi } \\
\hline Nilai & Frek & Nilai & Frek & Nilai & Frek & Nilai & Frek \\
\hline 64 & 2 & 64 & 2 & 70 & 3 & 69 & 1 \\
\hline 65 & 3 & 65 & 2 & 71 & 5 & 74 & 1 \\
\hline 66 & 3 & 68 & 1 & 73 & 4 & 75 & 1 \\
\hline 68 & 3 & 69 & 1 & 74 & 1 & 78 & 2 \\
\hline 70 & 3 & 70 & 2 & 75 & 1 & 79 & 1 \\
\hline 73 & 2 & 71 & 2 & 76 & 2 & 80 & 3 \\
\hline 76 & 2 & 73 & 3 & 79 & 1 & 81 & 2 \\
\hline 78 & 1 & 76 & 1 & 84 & 1 & 84 & 1 \\
\hline 80 & 1 & 79 & 1 & 86 & 1 & 85 & 2 \\
\hline Jumlah & 20 & 80 & 1 & Jumlah & 19 & 86 & 2 \\
\hline Rerata & 69.55 & Jumlah & 16 & Rerata & 74.05 & 90 & 1 \\
\hline & & Rerata & 70.5 & & & Jumlah & 17 \\
\cline { 2 - 3 } & & & & & & Rerata & 80.65 \\
\hline
\end{tabular}

Tabel 9. Data Disain Faktorial Model Pembelajaran Terhadap Kelompok PKA

\begin{tabular}{|c|c|c|c|}
\hline \multirow{2}{*}{$\begin{array}{c}\text { Tingkat } \\
\text { Pemahaman } \\
\text { Konsep } \\
\text { Awal }\end{array}$} & \multicolumn{2}{|c|}{$\begin{array}{c}\text { Rerata Hasil } \\
\text { Belajar }\end{array}$} & \\
\hline & DI & KGI & \\
\hline Rendah & 69,55 & 74,05 & 71,74 \\
\hline \multirow[t]{2}{*}{ Tinggi } & 70,50 & 80,65 & 75,82 \\
\hline & 70,05 & 76,17 & \\
\hline
\end{tabular}

Deskripsi statistik output dari ANAVA data hasil belajar pada model pembelajaran dan pemahaman konsep awal dapat dilihat pada Tabel 10.

Tabel 10. Jumlah Siswa Model Pembelajaran Terhadap PKA

\begin{tabular}{lclc}
\hline & & Value Label & Jumlah \\
\hline Model & 1 & DI & 36 \\
\cline { 2 - 4 } Pembelajaran & 2 & KGI & 36 \\
\hline Pemahaman & 1 & Rendah & 39 \\
\cline { 2 - 4 } Konsep Awal & 2 & Tinggi & 33 \\
\hline
\end{tabular}


Tabel 10 diperoleh bahwa jumlah siswa keseluruhan pada kelas eksperimen sebesar 36 orang dan pada kelas kontrol sebesar 36 orang. Jumlah siswa pada tingkat pemahaman konsep awal tinggi sebesar 33 orang dan pemahaman konsep rendah sebesar 39 orang. Uji Homogenitas ditunjukan pada Tabel 11.

Tabel 11. Uji Homogenitas Dari Varians

\begin{tabular}{lrrr}
\hline F & df1 & df2 & Sig. \\
\hline 0.182 & 3 & 68 & 0.908 \\
\hline
\end{tabular}

Tabel 11 menunjukan uji homogenitas data, diperoleh $\mathrm{F}_{\text {hitung }}$ sebesar 0,182 dengan signifikansi 0,908 lebih besar dari $\alpha=0,05$, maka data dinyatakan homogen untuk kemudian dilanjutkan pada pengujian ANAVA dua jalur. Hasil pengujian ANAVA dua jalur dapat dilihat pada Tabel 12.

Tabel 12. Output perhitungan ANAVA Dua Jalur

\begin{tabular}{lcrrrr} 
& $\begin{array}{l}\text { Type III } \\
\text { Sum of }\end{array}$ & \multicolumn{4}{c}{$\begin{array}{c}\text { Mean } \\
\text { Squar }\end{array}$} \\
Source & Squares & df & e & F & Sig. \\
\hline MODEL & & & 933.9 & 39.17 & \\
& 933.915 & 1 & 15 & 2 & 0.001 \\
\hline TK_PKA & & & 266.9 & 11.19 & \\
& 266.941 & 1 & 41 & 6 & 0.001 \\
\hline MODEL * & & & 132.9 & & \\
K_PKA & 132.964 & 1 & 64 & 5.577 & 0.021 \\
\hline
\end{tabular}

Berdasarkan pada tabel diatas, maka hipotesis statistik yang diperoleh adalah:

1. Hipotesis pertama yang diajukan $\mathrm{H}_{\mathrm{a}}$ diterima, yaitu ada perbedaan Hasil Belajar siswa yang diajarkan dengan Model Pembelajaran Kooperatif Tipe Group Investigation dan siswa yang diajarkan dengan Model Pembelajaran konvensional.

2. Hipotesis kedua yang diajukan $\mathrm{H}_{\mathrm{a}}$ diterima, yaitu ada perbedaan Hasil Belajar siswa yang memiliki Pemahaman Konsep Awal tinggi dan siswa yang memiliki Pemahaman Konsep Awal rendah.

3. Hipotesis ketiga yang diajukan $\mathrm{H}_{\mathrm{a}}$ diterima, yaitu Terdapat interaksi antara model pembelajaran dan Pemahaman Konsep Awal terhadap Hasil Belajar Fisika siswa.

Tingkat pemahaman konsep awal diperoleh $\mathrm{F}_{\text {hitung }}$ sebesar 5,58 dan signifikansi 0,021 $\left(\mathrm{F}_{\text {tabel }}=1,84, \alpha=0,05\right)$. Hasil ini menunjukkan bahwa $F_{\text {hitung }}>F_{\text {tabel }}$ dan signifikan lebih kecil dibandingkan signifikan $\alpha=0,05$, maka terdapat interaksi antara model pembelajaran dengan pemahaman konsep awal siswa untuk meningkatkan hasil belajar siswa. Hal ini dapat terlihat jelas pada Gambar 2.

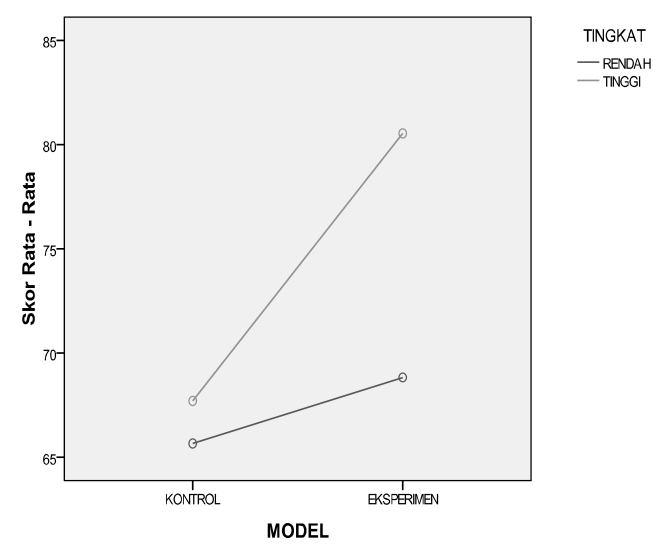

Gambar 2. Interaksi Anava 2 Jalur

Dari gambar 2 terlihat grafik interaksi antara Model Pembelajaran dan Pemahaman Konsep Awal dalam meningkatkan Hasil Belajar Fisika. Kedua garis berdekatan di satu titik (akan berpotongan jika garis diperpanjang) yang menunjukan bahwa terdapat interaksi yang signifikan antara Model Pembelajaran dan Pemahaman Konsep Awal dalam meningkatkan Hasil Belajar Fisika.

\section{KESIMPULAN}

Berdasarkan hasil analisa data, temuan dan pembahasan selama pembelajaran dengan menggunakan model pembelajaran Group Investigation dengan menekankan pada Pemahaman Konsep Awal dan hasil belajar, diperoleh beberapa kesimpulan yang merupakan jawaban atas pertanyaan-pertanyaan yang diajukan dalam rumusan masalah. Kesimpulankesimpulan tersebut adalah sebagai berikut: 
1. Terdapat perbedaan hasil belajar fisika siswa dengan model pembelajaran kooperatif tipe Group Investigation dan model pembelajaran Direct Instruction.

2. Terdapat perbedaan hasil belajar fisika antara siswa yang memiliki pemahaman konsep awal rendah dan pemahaman konsep awal tinggi.

3. Terdapat interaksi antara model pembelajaran kooperatif group investigation dan pemahaman konsep siswa terhadap hasil belajar fisika.

\section{DAFTAR PUSTAKA}

Dick and Carey. 2005. The Systematic Design of Instrustional Sixth Edition. Florida: Florida State University.

Dahar, R.W. 2011. Teori-teori Belajar. Jakarta: Erlangga.

Joyce, Bruce dkk. 2011. Models Of Teching Model-Model Pembelajaran. Yogyakarta: Pustaka Pelajar. 